\title{
Cardiac surgery with deep hypothermic circulatory arrest produces less systemic inflammatory response than low- flow cardiopulmonary bypass in newborns
}

P. Tassani, MD
A. Barankay, MD
F. Haas, MD
S. U. Paek, MD
M. Heilmaier
J. Hess, MD
R. Lange, MD
J. A. Richter, MD

From the Departments of Anesthesiology, ${ }^{a}$ Cardiovascular Surgery, ${ }^{\text {b }}$ and Pediatric Cardiology, ${ }^{\mathrm{c}}$ Deutsches Herzzentrum München, München, Germany

Read at the Eighty-first Annual Meeting of The American Association for Thoracic Surgery, San Diego, Calif, May 6-9, 2001.

Received for publication May 29, 2001; revisions requested July 5, 2001; revisions received July 24, 2001; accepted for publication Aug 31, 2001.

Address for reprints: Peter Tassani, MD, Department of Anesthesiology, Deutsches Herzzentrum München, Lazarettstr 36, 80636 München, Germany (E-mail: tassani@dhm.mhn.de).

J Thorac Cardiovasc Surg 2002;123:648-54

Copyright (C) 2002 by The American Association for Thoracic Surgery

0022-5223/2002 $\$ 35.00+0 \quad \mathbf{1 2 / 6 / 1 2 1 2 8 5}$

doi:10.1067/mtc.2002.121285
Objective: We sought to compare low-flow cardiopulmonary bypass with deep hypothermic circulatory arrest in respect to the influence on the systemic inflammatory response.

Methods: Twenty-three infants weighing less than $10 \mathrm{~kg}$ and scheduled for repair of congenital malformations were enrolled in a randomized, controlled study. Eleven patients underwent cardiac surgery with deep hypothermic circulatory arrest (the DHCA group). Low-flow cardiopulmonary bypass was used in another 12 patients (the LF group). Interleukin 6 and 8 and anaphylatoxin C3a levels were measured 6 times perioperatively. Also, perioperative weight gain and a radiologic soft-tissue index were compared.

Results: All patients had an uneventful clinical course. Duration of deep hypothermic circulatory arrest was $40 \pm 4$ minutes; the bypass time was significantly shorter in the DHCA group ( $85 \pm 8$ vs $130 \pm 19$ minutes). However, the duration of the operation was similar in both groups $(245 \pm 30$ vs $246 \pm 30$ minutes). During cardiopulmonary bypass (rewarming), the concentration of $\mathrm{C} 3 \mathrm{a}(3751 \pm 388 \mathrm{vs}$ $5761 \pm 1688 \mathrm{ng} / \mathrm{mL}$, mean $\pm \mathrm{SEM}$ ) was significantly lower in the DHCA group than in the LF group. The interleukin 8 level was significantly lower, and the interleukin 6 level had a tendency to be lower in the DHCA group compared with levels in the LF group. There was less weight gain on the first postoperative day in the DHCA group $(65 \pm 61$ vs $408 \pm 118 \mathrm{~g})$. The soft-tissue index suggested reduced edema formation in the DHCA group.

Conclusion: Deep hypothermic circulatory arrest produces less systemic inflammatory response than low-flow cardiopulmonary bypass. In addition, there is an indication of less fluid accumulation postoperatively.

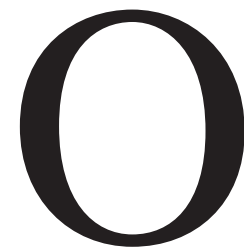
$\mathrm{n}$ the basis of the pioneering work of Mohri, Barratt-Boyes, and others, ${ }^{1-5}$ congenital heart defects in newborns and infants have been corrected by using deep hypothermic circulatory arrest (DHCA). This technique has provided excellent early and late results. Because of increased evidence of associated neurologic morbidity with prolonged periods of circulatory arrest, many surgical teams have favored hypothermia and low-flow cardiopulmonary bypass (LF-CPB) recently. The effect of the 2 different perfusion strategies on organ function and postoperative hemodynamic data have already been investigated. ${ }^{6-11}$ 
Also, the immune response to CPB has been the subject of previous investigations. ${ }^{12}$ Although it is well known that $\mathrm{CPB}$ also induces the release of a variety of inflammatory mediators in pediatric patients, ${ }^{13}$ the effect of DHCA and LF-CPB on systemic inflammatory response in infants has not yet been investigated systematically. The aim of our study was to compare these 2 strategies in respect to their supposed effect on the activation of the complement system represented by changes of anaphylatoxin $\mathrm{C} 3 \mathrm{a}$ and the proinflammatory mediators interleukin 6 and interleukin 8 .

\section{Methods}

This study was approved by the institutional ethics committee, and all parents provided written informed consent. Twenty-three infants and newborns weighing less than $10 \mathrm{~kg}$ and scheduled for elective repair of congenital heart diseases were randomized (by using electronically generated numbers) for operation with predominantly DHCA or the low-flow perfusion technique. In the DHCA group $(n=11)$ DHCA was instituted for the correction of the lesion; CPB was mainly used for cooling and subsequent rewarming. In the LF group $(n=12)$ the low-flow perfusion technique was used during the operation. Flunitrazepam $(0.04$ $\mathrm{mg} / \mathrm{kg}$; Rohypnol; Roche, Grenzach, Germany) and atropine (0.01 $\mathrm{mg} / \mathrm{kg}$; Braun, Melsungen, Germany) were administered together intramuscularly 45 minutes before the induction of anesthesia. After the arrival of the patient in the operating room, a blood pressure cuff, electrocardiogram recording, and pulse oximetry (Marquette, Milwaukee, Wis) were applied. Anesthesia was performed as a total intravenous technique with sufentanil, midazolam, and rocuronium bromide. After nasotracheal intubation, mechanical ventilation with $100 \%$ oxygen was provided by means of a nonrebreathing system, maintaining arterial carbon dioxide tension between 30 and $40 \mathrm{~mm} \mathrm{Hg}$, and monitored with mass spectroscopy and blood gas analysis. A 24-gauge radial artery catheter (Jelco; Ethicon, Pomezia, Italy), and a 4F double-lumen central venous catheter (Arrow, Reading, Pa) were placed percutaneously through the right internal jugular vein. Measurements of hemodynamics included heart rate, mean arterial pressure, and central venous pressure.

Infants underwent spontaneous cooling because of the cool ambient temperature of the operating room during induction of anesthesia. Using a cooling blanket (Blanketrol II; Cincinnati Sub Zero, Cincinnati, Ohio), a rectal temperature of $32^{\circ} \mathrm{C}$ to $33^{\circ} \mathrm{C}$ was reached at the commencement of CPB.

The pump was primed with $250 \mathrm{~mL}$ of packed cells and 250 $\mathrm{mL}$ of fresh-frozen plasma, to which $100 \mathrm{~mL}$ of lactated Ringer's solution, $1000 \mathrm{IU}$ of heparin, $2.5 \mathrm{~mL} / \mathrm{kg}$ sodium bicarbonate $4.2 \%$, and $3 \mathrm{~mL} / \mathrm{kg}$ mannitol $20 \%$ were added. After systemic anticoagulation with $3 \mathrm{mg} / \mathrm{kg}$ heparin and administration of $1 \mathrm{mg} / \mathrm{kg}$ dexamethasone, CPB was instituted at a flow rate of 2.4 $\mathrm{L} \cdot \mathrm{min}^{-1} \cdot \mathrm{m}^{-2}$. During rewarming, ultrafiltration was performed for a maximum of 20 minutes or until the level of the venous reservoir was at the lower level. After weaning from CPB, all patients underwent modified ultrafiltration for the same time period.

\section{DHCA Group}

In patients in the DHCA group, an arterial cannula was placed in the ascending aorta; for venous return, one cannula was inserted in the right atrium. Then systemic hypothermia was induced until an esophageal temperature of $16^{\circ} \mathrm{C}$ and a rectal temperature of $18^{\circ} \mathrm{C}$ were achieved. Before the start of DHCA, the CPB flow rate was decreased by half. After crossclamping the aorta, $50 \mathrm{~mL} / \mathrm{kg}$ cold crystalloid cardioplegic solution (Bretschneider, Custodiol; Köhler Chemie, Alsbach-Hähnlein, Germany) was infused through the aortic root. Alpha-stat acid-base management was used during hypothermic CPB to maintain an uncorrected arterial carbon dioxide tension of $40 \mathrm{~mm} \mathrm{Hg}$. After the above-mentioned temperatures had been achieved, circulatory arrest was begun. After correction of the congenital malformation, $\mathrm{CPB}$ was started at 1.2 $\mathrm{L} \cdot \mathrm{min}^{-1} \cdot \mathrm{m}^{-2}$, and a total flow of $2.4 \mathrm{~L} \cdot \mathrm{min}^{-1} \cdot \mathrm{m}^{-2}$ was maintained during rewarming at a rectal temperature of more than $28^{\circ} \mathrm{C}$. The difference between the perfusate and rectal temperature was less than $10^{\circ} \mathrm{C}$ during rewarming.

\section{LF Group}

Instead of using one venous cannula in the right atrium, patients in the LF group underwent bicaval cannulation. Cooling was performed until rectal temperature was less than $24^{\circ} \mathrm{C}$. A stable flow of $1.2 \mathrm{~L} \cdot \mathrm{min}^{-1} \cdot \mathrm{m}^{-2}$ was maintained thereafter during the period of intracardiac correction. After crossclamping the aorta, $50 \mathrm{~mL} / \mathrm{kg}$ cold crystalloid cardioplegic solution (Bretschneider, Custodiol, Köhler Chemie) was infused through the aortic root. Alpha-stat acid-base management was used during hypothermic CPB to maintain an uncorrected arterial carbon dioxide tension of $40 \mathrm{~mm}$ $\mathrm{Hg}$. During rewarming, the flow rate was gradually increased to $2.4 \mathrm{~L} \cdot \mathrm{min}^{-1} \cdot \mathrm{m}^{-2}$.

\section{Samples and Measurements}

Blood samples were obtained, and hemodynamic measurements were performed at the following time points: (1) before the operation; (2) during $\mathrm{CPB}$ during rewarming and after DHCA in the DHCA group $\left(30^{\circ} \mathrm{C}\right.$ rectal temperature); (3) 30 minutes after CPB; (4) 2 hours after CPB; (5) 4 hours after CPB; and (6) 24 hours after CPB.

Anaphylatoxin $\mathrm{C} 3 \mathrm{a}$ was measured with a radioimmunoassay (Amersham, Little Chalfont, England), and interleukin 6 and interleukin 8 levels were measured with a solid-phase, 2-site chemiluminescent enzyme immunometric assay (Immulite System; Diagnostic Products Corp, Los Angeles, Calif).

A radiologic index was calculated as the ratio of the dimension of soft tissues measured at the height of the eighth rib to the diameter of the eighth rib measured at the midclavicular line to quantify the edema of the soft tissues. ${ }^{14}$ Measurements were performed on the preoperative chest radiographic film and on the first and second postoperative day.

\section{Statistics}

Before the study, a power calculation for a $20 \%$ difference in postoperative weight gain with a probability of type $\alpha$ error of $5 \%$ and a probability of type $\beta$ error of $20 \%$ yielded a sample size of 11 patients for each group. The group means were compared with the Mann-Whitney $U$ test (nonparametric). Results are presented 


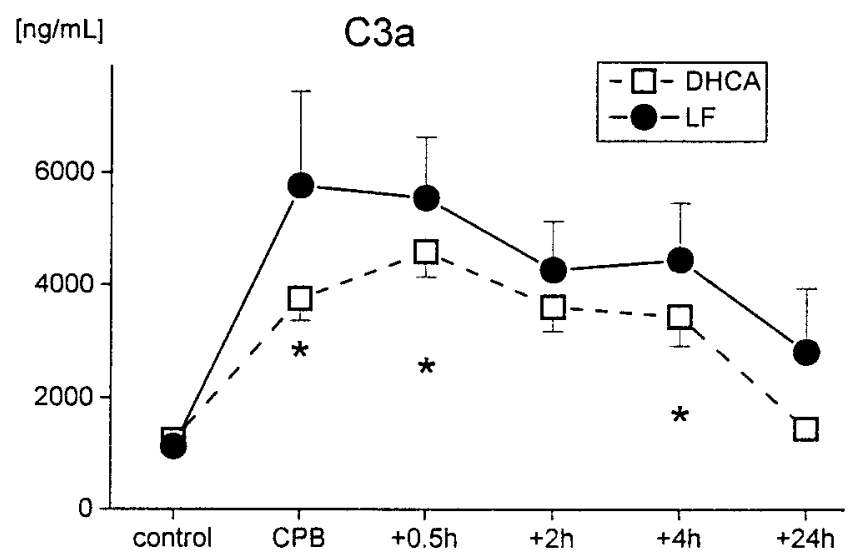

Figure 1. Concentration of C3a anaphylatoxin (in nanograms per milliliter). Control indicates the period after induction of anesthesia and before the operation. CPB indicates the period during CPB-rewarming, with a rectal temperature of $30^{\circ} \mathrm{C}$. $+0.5 h, 0.5$ hours after CPB; $+2 h, 2$ hours after CPB; $+4 h, 4$ hours after CPB; $+24 h$, 24 hours after CPB. *Significant difference noted between the groups $(P<.05$, Mann-Whitney $U$ test).

TABLE 1. Characteristics of patients and operative data

\begin{tabular}{lcc}
\hline & $\begin{array}{c}\text { DHCA group } \\
\text { (n = 11) }\end{array}$ & $\begin{array}{c}\text { LF group } \\
\text { (n = 12) }\end{array}$ \\
\hline Age (d) & $139 \pm 28$ & $84 \pm 21$ \\
Weight (g) & $4619 \pm 513$ & $5024 \pm 580$ \\
Height (cm) & $60.0 \pm 2.5$ & $60.5 \pm 3.0$ \\
Operation-time (min) & $245 \pm 30$ & $246 \pm 30$ \\
CPB time (min) & $85 \pm 8$ & $130 \pm 19$ \\
Aortic clamp time (min) & $70 \pm 8$ & $72 \pm 6$ \\
DHCA time (min) & $40 \pm 4$ & - \\
MUF duration (min) & $9 \pm 0.9$ & $11.5 \pm 1.5$ \\
MUF quantity (mL) & $127 \pm 19$ & $182 \pm 20$ \\
UF duration (min) & $20 \pm 2$ & $18 \pm 4$ \\
UF quantity (mL) & $356 \pm 37$ & $220 \pm 73$ \\
\end{tabular}

MUF, Modified ultrafiltration; UF, ultrafiltration.

as means \pm SEM. Differences were considered to be statistically significant when the probability of type $\alpha$ error was less than $5 \%$.

\section{Results}

There were no demographic differences between the 2 groups (Table 1). Twenty-three patients completed the study. In the DHCA group there were 5 patients with a complete atrioventricular canal defect, 1 with common truncus arteriosus, 1 with total anomalous pulmonary venous return, and 4 with ventricular septal defect. In the LF group there was 1 patient with a complete atrioventricular canal defect, 6 with ventricular septal defect, 3 with transposition of the great arteries, and 2 with tetralogy of Fallot.

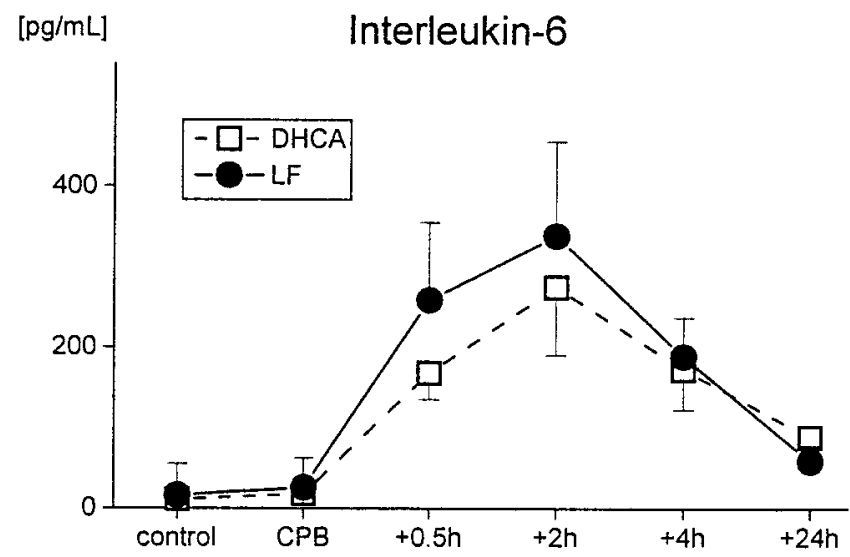

Figure 2. Concentration of interleukin 6 (in picograms per milliliter). Control indicates the period after induction of anesthesia and before the operation. CPB indicates the period during CPBrewarming, with a rectal temperature of $30^{\circ} \mathrm{C}$. $+0.5 h, 0.5$ hours after CPB; $+2 h, 2$ hours after CPB; $+4 h, 4$ hours after CPB; $+24 h$, 24 hours after CPB. *Significant difference noted between the groups $(P<.05$, Mann-Whitney $U$ test $)$.

\section{Intraoperative Data}

Intraoperative data are shown in Table 1. As a result of a major portion of the operative correction being performed during DHCA ( $40 \pm 4$ minutes; range, 18-60 minutes), the CPB time was shorter in this group $(85 \pm 8$ vs $130 \pm 19$ minutes). However, the duration of the operation was similar in both groups ( $245 \pm 30$ vs $246 \pm 30$ minutes).

\section{Inflammatory Response}

Inflammatory response data are shown in Figures 1 through 3. Figure 1 shows the significant lower concentration of anaphylatoxin 3a in DHCA patients versus that in LF patients $(3751 \pm 388$ vs $5761 \pm 1688 \mathrm{ng} / \mathrm{mL}$ during $\mathrm{CPB}$ while rewarming the patient). The concentration of interleukin 6 shows a tendency to be lower in DHCA patients versus that seen in LF patients at 0.5 and 2 hours after CPB. The concentration of interleukin 8 was significantly lower in DHCA patients $(64 \pm 12$ vs $116 \pm 44$ pg/mL, Figure 3$)$.

\section{Hemodynamic Parameters}

Hemodynamic parameters are presented in Table 2. The mean arterial pressure is significantly higher in DHCA patients after $\mathrm{CPB}$ compared with that in LF patients 2 hours after CPB (60 \pm 2 vs $54 \pm 3 \mathrm{~mm} \mathrm{Hg})$. There were no significant differences found concerning heart rate and central venous pressure between the 2 groups. Both patient groups required positive inotropic stimulation after CPB. Although the mean doses of dopamine used in the 2 groups were similar, significantly more dobutamine $(2.1 \pm 1.0 \mathrm{vs}$ $\left.0.7 \pm 0.5 \mu \mathrm{g} \cdot \mathrm{kg}^{-1} \cdot \mathrm{min}^{-1}, P<.05\right)$ was required in $\mathrm{LF}$ patients 2 hours after CPB. 


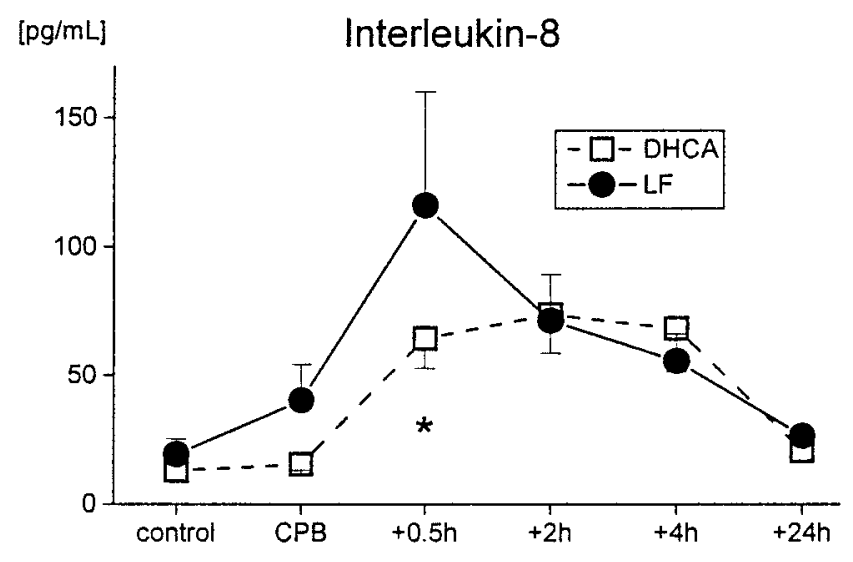

Figure 3. Concentration of interleukin 8 (in picograms per milliliter). Control indicates the period after induction of anesthesia and before the operation. CPB indicates the period during CPBrewarming, with a rectal temperature of $30^{\circ} \mathrm{C} .+0.5 \mathrm{~h}, 0.5$ hours after $\mathrm{CPB} ;+2 h$, 2 hours after $\mathrm{CPB} ;+4 h, 4$ hours after $\mathrm{CPB} ;+24 h$, 24 hours after $\mathrm{CPB}$. *Significant difference noted between the groups $(P<.05$, Mann-Whitney $U$ test).

TABLE 2. Hemodynamic parameter and cardiovascular drugs

\begin{tabular}{|c|c|c|c|c|}
\hline & Control & CPB & $\begin{array}{l}\text { CPB } \\
+0.5 \mathrm{~h}\end{array}$ & $\begin{array}{l}\text { CPB } \\
+2 h\end{array}$ \\
\hline HR, DHCA group $\left(\min ^{-1}\right)$ & $116 \pm 4$ & - & $143 \pm 5$ & $139 \pm 4$ \\
\hline HR, LF group $\left(\min ^{-1}\right)$ & $130 \pm 5$ & - & $151 \pm 3$ & $147 \pm 4$ \\
\hline $\begin{array}{l}\text { MAP, DHCA group } \\
(\mathrm{mm} \mathrm{Hg})\end{array}$ & $48 \pm 3$ & $47 \pm 3$ & $56 \pm 3$ & $60 \pm 2^{*}$ \\
\hline MAP, LF group (mm Hg) & $51 \pm 2$ & $45 \pm 2$ & $52 \pm 3$ & $54 \pm 3$ \\
\hline $\begin{array}{l}\text { CVP, DHCA group } \\
(\mathrm{mm} \mathrm{Hg})\end{array}$ & $6 \pm 1$ & - & $9 \pm 1$ & $10 \pm 1$ \\
\hline CVP, LF group (mm Hg) & $8 \pm 1$ & - & $11 \pm 1$ & $9 \pm 1$ \\
\hline $\begin{array}{l}\text { Hematocrit, DHCA group } \\
(\%)\end{array}$ & $31 \pm 4$ & $25 \pm 4$ & $37 \pm 6$ & $41 \pm 6$ \\
\hline $\begin{array}{l}\text { Hematocrit, LF group } \\
(\%)\end{array}$ & $33 \pm 3$ & $25 \pm 4$ & $34 \pm 4$ & $40 \pm 6$ \\
\hline $\begin{array}{l}\text { Dopamine, DHCA group } \\
\left(\mu \mathrm{g} \cdot \mathrm{kg}^{-1} \cdot \mathrm{min}^{-1}\right)\end{array}$ & - & $2.4 \pm 0.5$ & $4.5 \pm 0.4$ & $4.5 \pm 0.3$ \\
\hline $\begin{array}{l}\text { Dopamine, LF group } \\
\left(\mu \mathrm{g} \cdot \mathrm{kg}^{-1} \cdot \min ^{-1}\right)\end{array}$ & - & $2.8 \pm 0.4$ & $4.0 \pm 0.4$ & $2.3 \pm 0.6$ \\
\hline $\begin{array}{l}\text { Dobutamine, DHCA group } \\
\left(\mu \mathrm{g} \cdot \mathrm{kg}^{-1} \cdot \min ^{-1}\right)\end{array}$ & - & - & $0.7 \pm 0.5^{*}$ & $0.7 \pm 0.5^{*}$ \\
\hline $\begin{array}{l}\text { Dobutamine, LF group } \\
\left(\mu \mathrm{g} \cdot \mathrm{kg}^{-1} \cdot \min ^{-1}\right)\end{array}$ & - & - & $3.2 \pm 1.2$ & $2.1 \pm 1.0$ \\
\hline
\end{tabular}

Values are presented as means \pm SEM.

Control, Start of anesthesia; $C P B$, during $C P B$ and start of rewarming; $C P B$

$+0.5 h, 0.5$ hours after $C P B ; C P B+2 h, 2$ hours after $C P B ; H R$, heart rate; $M A P$, Mean arterial pressure; $C V P$, central venous pressure.

${ }^{*} P<.05, t$ test.

\section{Clinical Data}

Clinical data are shown in Tables 3 and 4 and Figure 4. Body weight at the first 3 postoperative days minus preoperative body weight (weight gain) was lower in DHCA [g]

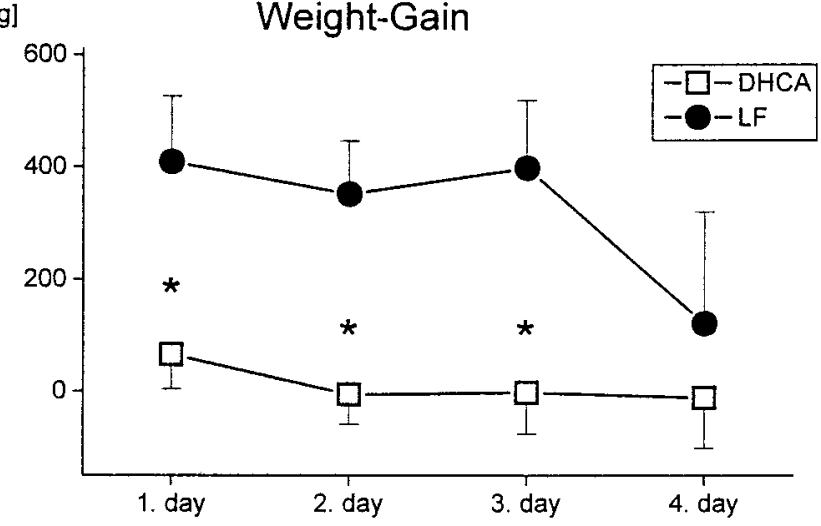

Figure 4. Weight gain (in grams): weight of the patient at the respective postoperative day minus the preoperative weight.

\section{TABLE 3. Postoperative data}

\begin{tabular}{lrrc}
\hline & DHCA group & \multicolumn{1}{c}{ LF group } & P value \\
\hline Duration of ventilation (d) & $7.4 \pm 3.3$ & $3.3 \pm 0.8$ & .46 \\
Fluid balance, day 1 (mL) & $-195 \pm 71$ & $-30 \pm 60$ & .44 \\
Fluid balance, day 2 (mL) & $-62 \pm 43$ & $-134 \pm 60$ & .88 \\
Fluid balance, day 3 (mL) & $+13 \pm 36$ & $-66 \pm 59$ & .19 \\
Fluid balance, day 4 (mL) & $+19 \pm 24$ & $+123 \pm 61$ & .21 \\
Chest tube drainage (mL) & $117 \pm 29$ & $109 \pm 12$ & .89 \\
\hline
\end{tabular}

Values are presented as mean \pm SEM.

Fluid balance, Fluid intake minus urine output at the respective postoperative day.

TABLE 4. Radiologic index

\begin{tabular}{lccc}
\hline & DHCA group & LF group & $P$ value \\
\hline Preoperative index & $1.72 \pm 0.3$ & $2.1 \pm 0.4$ & .46 \\
Index at POD 1 & $1.69 \pm 0.2$ & $2.44 \pm 0.3$ & .043 \\
Index at POD 2 & $1.80 \pm 0.2$ & $3.10 \pm 0.5$ & .019
\end{tabular}

The radiological index was calculated as the ratio of the dimension of soft tissues measured at the height of the eighth rib to the diameter of the eighth rib measured at the midclavicular line. $P O D$, Postoperative day.

patients compared with that in LF patients (first postoperative day: $65 \pm 61$ vs $408 \pm 118 \mathrm{~g}, P<.05$, Figure 4$)$. The radiologic soft-tissue index was also lower $(P<.05)$ in DHCA patients compared with that in LF patients (Table 4).

\section{Discussion}

Nowadays, most congenital heart defects can be operated on with a continuous perfusion technique. Nevertheless, DHCA provides unparalleled surgical exposure in the small heart by eliminating the need for multiple cannulas within the field. In some anomalies (total anomalous pulmonary venous return, interrupted aortic arch, and hypoplastic left heart syndrome in some cases) its use is still preferable.

Excellent clinical results have been published on a series 
of 120 Fontan or Fontan-like operations with the DHCA technique. ${ }^{15}$ The postoperative morbidity in respect to the development of pleural effusions and ascites was extremely low in this group of patients. It is conceivable that reduced systemic inflammatory response with DHCA is one reason for the smooth postoperative course of these patients; inflammatory mediators have, however, not been measured. ${ }^{15}$

Therefore, this study investigated the inflammatory response with the 2 different perfusion techniques: DHCA versus continuous low-flow perfusion. Levels of anaphylatoxin $\mathrm{C} 3 \mathrm{a}$ and the proinflammatory chemokine interleukin 8 were found to be significantly lower in patients after DHCA compared with in patients after LF-CPB. Proinflammatory interleukin 6 showed a tendency to be lower in patients after DHCA.

There are 2 main reasons potentially leading to reduced inflammatory response after DHCA: (1) shorter duration of $\mathrm{CPB}$ and (2) lower temperature.

Duration of CPB was significantly lower in patients after DHCA compared with patients after LF-CPB. A correlation between duration of $\mathrm{CPB}$ and inflammatory response has already been reported. ${ }^{16,17}$ The second factor might be the lower temperature $\left(18^{\circ} \mathrm{C}\right)$ in the DHCA group compared with that in the $\mathrm{LF}$ group $\left(24^{\circ} \mathrm{C}\right)$. However, the effect of temperature on inflammatory response is not a linear relationship. It is already known that tepid temperature during $\mathrm{CPB}\left(32^{\circ} \mathrm{C}-34^{\circ} \mathrm{C}\right)$ is associated with reduced systemic inflammatory response compared with that during normothermic CPB. ${ }^{18} \mathrm{~A}$ recently published investigation in 24 pigs with normothermia $\left(37^{\circ} \mathrm{C}\right)$, moderate hypothermia $\left(28^{\circ} \mathrm{C}\right)$, or deep hypothermia $\left(20^{\circ} \mathrm{C}\right)$ showed that moderate hypothermia is associated with lower concentrations of proinflammatory mediators and higher concentrations of antiinflammatory mediators compared with concentrations in the other 2 groups. ${ }^{19}$ Moderate hypothermia was associated with the lowest histologic organ damage score, and normothermia was associated with the highest score. ${ }^{19}$ Therefore, higher levels of inflammatory mediators had to be expected in the DHCA group $\left(18^{\circ} \mathrm{C}\right)$ compared with those in the LF-CPB group $\left(24^{\circ} \mathrm{C}\right)$, which is in contrast to the findings of the present investigation.

Another factor potentially influencing the inflammatory reaction is the degree of the hypoxemia in these patients. In cyanotic patients inflammatory response was already stimulated before the operation. ${ }^{20}$ In our population there are 2 patients in the DHCA group with a cyanotic lesion and 5 in the LF group. However, the patients with transposition of the great arteries had a balloon atrioseptostomy before the operation, and the oxygen saturation was more than $85 \%$ in every one of the patients. In addition, no differences in the baseline levels of either mediator could be detected between the 2 study groups. In regard to preexisting congestive heart failure, there was one patient in the DHCA group who received digitoxin; no patients received catecholamines, however.

In the present investigation clinical parameters, such as mean arterial pressure, postoperative weight gain, and a radiologic soft-tissue index, also seem to suggest a superior postoperative course after DHCA compared with after LF$\mathrm{CPB}$. The higher arterial pressure after CPB in DHCA patients compared with that in LF patients may be the result of reduced vasodilation caused by reduced inflammatory response ( $\mathrm{C} 3 \mathrm{a}$ and interleukin 8). This is in concordance with another investigation, in which the incidence of vasodilation necessitating vasopressor support was 2 -fold higher in a group of patients undergoing normothermic $\mathrm{CPB}$ compared with in patients undergoing hypothermic $\mathrm{CPB} .{ }^{18} \mathrm{Re}-$ duced weight gain postoperatively may reflect reduced capillary leakage, which has been shown to be associated with the inflammatory response syndrome.${ }^{14}$ However, the transcapillary escape rate of protein has to be determined to really measure capillary leakage, which has not been done in this investigation. Reduced weight gain after $\mathrm{CPB}$ in patients after DHCA may be the result of the shorter CPB duration in addition to the reduced inflammatory response. Patients who underwent a Fontan operation are extremely sensitive to fluid accumulation and fluid shifts after CPB. Therefore, it seems obvious that DHCA and also modified ultrafiltration lead to a superior clinical outcome. ${ }^{15} \mathrm{~A}$ significantly higher survival rate has been reported recently by Mosca and associates, ${ }^{21}$ who used DHCA in 100 consecutive patients with hypoplastic left heart syndrome. Although ultrafiltration raises colloid osmotic pressure and hematocrit levels, a significant reduction of inflammatory mediators could not be demonstrated. ${ }^{22}$

The results of the present investigation are in line with those of the Boston Circulatory Arrest Study, in which patients had significantly less weight gain after DHCA. ${ }^{7,23,24}$ Ischemia and subsequent reperfusion of isolated organs lead to significant production of inflammatory mediators in the respective organs. This has been proven for the heart ${ }^{25}$ and also for the lungs. ${ }^{26,27}$ In contrast to these results, a similar effect does not play a decisive role for the whole body in the case of DHCA, according to the data of our study.

Although nonneurologic outcome in the arterial switch operation did not differ between those receiving the DHCA and LF-CPB techniques, ${ }^{8}$ there is always concern about neurologic deficits after use of DHCA. Profound hypothermia $\left(18^{\circ} \mathrm{C}\right)$ reduces systemic metabolism to $16 \%$ of control levels, but cerebral metabolism is only reduced to $32 \%$ to $40 \%$ of control levels in an animal model. ${ }^{28}$ Children show developmental delays on specific neuropsychologic testing after either LF-CPB or DHCA. Up to $10 \%$ of infants have been shown to exhibit seizures after DHCA. ${ }^{29}$ Furthermore, a linear relationship between the duration of DHCA and IQ 
has been suggested. ${ }^{30}$ No attempt was made, however, to investigate the neurologic sequelae of the 2 different perfusion techniques in the present investigation.

Inflammatory response is reduced by the use of DHCA compared with the reduction seen with low-flow perfusion. A shorter duration of $\mathrm{CPB}$ and a lower body temperature may contribute to this finding, whereas ischemia and reperfusion of the whole body do not seem to play a major role.

We thank U. Hess, MD, who measured the radiologic index, and S. L. Braun, MD, and Mrs Löschenkohl, who determined the inflammatory mediators.

\section{References}

1. Mohri H, Hessel EA, Nelson RJ, Matano I, Anderson HN, Dillard DH, et al. Use of rheomacrodex and hyperventilation in prolonged circulatory arrest under deep hypothermia induced by surface cooling: method for open heart surgery in infants. Am J Surg. 1966;112:241-50.

2. Barratt-Boyes BG, Simpson M, Neutze JM. Intracardiac surgery in neonates and infants using deep hypothermia with surface cooling and limited cardiopulmonary bypass. Circulation. 1971;43(Suppl):I-2530.

3. Barratt-Boyes BG, Neutze JM, Seelye ER, Simpson M. Complete correction of cardiovascular malformations in the first year of life. Prog Cardiovasc Dis. 1972;15:229-53.

4. Castaneda AR, Lamberti J, Sade RM, Williams RG, Nadas AS. Open-heart surgery during the first three months of life. J Thorac Cardiovasc Surg. 1974;68:719-31.

5. Doty DB, Lauer RM, Ehrenhaft JL. Congenital cardiac anomalies: one-stage repair in infancy. Ann Thorac Surg. 1975;20:316-25.

6. Jonas RA, Bellinger DC, Rappaport LA, Wernovsky G, Hickey PR, Farrell DM, et al. Relation of $\mathrm{pH}$ strategy and developmental outcome after hypothermic circulatory arrest. J Thorac Cardiovasc Surg. 1993; 106:362-8.

7. Newburger JW, Jonas RA, Wernovsky G, Wypij D, Hickey PR, Kuban KC, et al. A comparison of the perioperative neurologic effects of hypothermic circulatory arrest versus low-flow cardiopulmonary bypass in infant heart surgery [see comments]. N Engl J Med. 1993; 329:1057-64

8. Wernovsky G, Wypij D, Jonas RA, Mayer JE Jr, Hanley FL, Hickey $\mathrm{PR}$, et al. Postoperative course and hemodynamic profile after the arterial switch operation in neonates and infants: a comparison of low-flow cardiopulmonary bypass and circulatory arrest. Circulation. 1995;92:2226-35.

9. Dapper F, Neppl H, Wozniak G, Strube I, Zickmann B, Hehrlein FW, et al. Effects of pulsatile and nonpulsatile perfusion mode during extracorporeal circulation-a comparative clinical study [see comments]. Thorac Cardiovasc Surg. 1992;40:345-51.

10. Dapper F, Neppl H, Wozniak G, Strube I, Boldt J, Hehrlein FW, et al. Influence of 4 different membrane oxygenators on inflammation-like processes during extracorporeal circulation with pulsatile and nonpulsatile flow. Eur J Cardiothorac Surg. 1992;6:18-24.

11. Quigley RL, Caplan MS, Perkins JA, Arentzon CE, Alexander JC, Kuehn BE, et al. Cardiopulmonary bypass with adequate flow and perfusion pressures prevents endotoxaemia and pathologic cytokine production. Perfusion. 1995;10:27-31.

12. Levy J. The human inflammatory response. J Cardiovasc Pharmacol. 1996;27(suppl 1):S31-7.

13. Seghaye MC, Duchateau J, Grabitz RG, Faymonville ML, Messmer BJ, Buro RK, et al. Complement activation during cardiopulmonary bypass in infants and children: relation to postoperative multiple system organ failure. J Thorac Cardiovasc Surg. 1993;106:978-87.

14. Seghaye MC, Grabitz RG, Duchateau J, Busse S, Dabritz S, Koch D, et al. Inflammatory reaction and capillary leak syndrome related to cardiopulmonary bypass in neonates undergoing cardiac operations. J Thorac Cardiovasc Surg. 1996;112:687-97.
15. Koutlas TC, Gaynor JW, Nicolson SC, Steven JM, Wernovsky G, Spray TL. Modified ultrafiltration reduces postoperative morbidity after cavopulmonary connection. Ann Thorac Surg. 1997;64:37-42.

16. Furunaga A, Tsuboi H, Itoh H, Kawamura T, Minami Y, Gohra H, et al. Significance of systemic inflammatory response syndrome at cardiopulmonary bypass [in Japanese]. Nippon Kyobu Geka Gakkai Zasshi. 1996;44:790-4.

17. Taggart DP, Sundaram S, McCartney C, Bowman A, McIntyre H, Courtney JM, et al. Endotoxemia, complement, and white blood cell activation in cardiac surgery: a randomized trial of laxatives and pulsatile perfusion. Ann Thorac Surg. 1994;57:376-82.

18. Menasché P, Haydar S, Peynet J, Du Buit C, Merval R, Bloch G, et al. A potential mechanism of vasodilation after warm heart surgery. J Thorac Cardiovasc Surg. 1994;107:293-9.

19. Quing M, Vazquez-Jimenez JF, Klosterhalfen B, Sigler M, Schumacher K, Duchateau J, et al. Influence of temperature during cardiopulmonary bypass on leukocyte activation, cytokine balance, and postoperative organ damage. Shock. 2001;15:372-7.

20. Seghaye MC, Hüffmeier U, Duchateau J, Messmer BJ, von Bernuth G. Cytokine balance related to cardiac operation in infants with preoperative cyanosis or heart failure [abstract]. Cardiol Young. 1999; 9(suppl 2):7.

21. Mosca RS, Kulik TJ, Goldberg CS, Vermilion RP, Charpie JR, Crowley DC, et al. Early results of the Fontan procedure in one hundred consecutive patients with hypoplastic left heart syndrome. $J$ Thorac Cardiovasc Surg. 2000;119:1110-8.

22. Tassani P, Richter JA, Eising GP, Barankay A, Braun SL, Haehnel $\mathrm{CH}$, et al. Influence of combined zero-balanced and modified ultrafiltration on the systemic inflammatory response during coronary artery bypass grafting. J Cardiothorac Vasc Anesth. 1999;13:285-91.

23. Bellinger DC, Jonas RA, Rappaport LA, Wypij D, Wernovsky G, Kuban KC, et al. Developmental and neurologic status of children after heart surgery with hypothermic circulatory arrest or low-flow cardiopulmonary bypass [see comments]. $N$ Engl J Med. 1995;332: 549-55.

24. Bellinger DC, Wypij D, Kuban KC, Rappaport LA, Hickey PR, Wernovsky G, et al. Developmental and neurological status of children at 4 years of age after heart surgery with hypothermic circulatory arrest or low-flow cardiopulmonary bypass. Circulation. 1999;100: 526-32.

25. Massoudy P, Zahler S, Barankay A, Becker BF, Richter JA, Meisner H. Sodium nitroprusside during coronary artery bypass grafting: evidence for an antiinflammatory action. Ann Thorac Surg. 1999;67: 1059-64.

26. Massoudy P, Zahler S, Becker BF, Braun SL, Barankay A, Richter JA, et al. Significant leukocyte and platelet retention during pulmonary passage after declamping of the aorta in CABG patients. Eur J Med Res. 1999;4:178-82.

27. Massoudy P, Zahler S, Tassani P, Becker BF, Richter JA, Pfauder M, et al. Reduction of pro-inflammatory cytokine levels and cellular adhesion in CABG procedures with separated pulmonary and systemic extracorporeal circulation without an oxygenator. Eur J Cardiothorac Surg. 2000;17:729-36.

28. Mezrow CK, Gandsas A, Sadeghi AM, Midulla PS, Shiang HH, Green $\mathrm{R}$, et al. Metabolic correlates of neurologic and behavioral injury after prolonged hypothermic circulatory arrest. J Thorac Cardiovasc Surg. 1995;109:959-75.

29. Ehyai A, Fenichel GM, Bender HW Jr. Incidence and prognosis of seizures in infants after cardiac surgery with profound hypothermia and circulatory arrest. JAMA. 1984;252:3165-7.

30. Oates RK, Simpson JM, Turnbull JA, Cartmill TB. The relationship between intelligence and duration of circulatory arrest with deep hypothermia [see comments]. J Thorac Cardiovasc Surg. 1995;110: 786-92.

\section{Discussion}

Dr Gerhard Ziemer (Tuebingen, Germany). Dr Tassani, I really liked your study. However, I think you missed one additional control group, which would be the group where you have the babies on full flow all the time. I do not think it is deep hypother- 
mia itself that reduces the inflammatory response and that makes you get less weight gain, but it is the effect of the low-flow period you have that makes you have this weight gain. So I think you should add one group with full flow all the time and then tell us what you find.

Dr Tassani. Thank you, Professor Ziemer, for this very good comment. According to our clinical practice, surgical correction is performed under the conditions of deep hypothermia combined with low-flow perfusion or total circulatory arrest. Reducing flow under hypothermic conditions ensures sufficient oxygen supply and provides better surgical conditions for corrections. We never practice full-flow perfusion combined with deep hypothermia. But I have to mention that cooling and rewarming was achieved in both groups with full-flow perfusion rates. In the LF group pump flow was reduced by $50 \%$ after $24^{\circ} \mathrm{C}$ was reached.

Dr Pedro J. del Nido (Boston, Mass). One important variable that you did not mention was hematocrit levels. If you have a significant amount of hemodilution and you keep a baby on bypass for an additional 40 or 50 minutes, I think it is very likely that this could easily explain the third-space increase. Could you tell us what the hematocrit level was in both groups?

Dr Tassani. During extracorporeal circulation, the hemoglobin value was about 7 to $8 \mathrm{~g} / \mathrm{dL}$, corresponding to the measured hematocrit of about $20 \%$ to $25 \%$. Pump priming was quite similar in both groups. I have not presented the data, but we found no statistical differences between the groups.

Dr del Nido. I suspect that if you maintain the hematocrit at $25 \%$ or close to $30 \%$, and in fact there are several clinical centers that have moved to this maneuver, you are going to eliminate a lot of your third-space fluid accumulation.

Dr Tassani. I think there are 2 important factors differing between the groups. First is the shorter exposition to extracorporeal circulation, and second is the lower temperature in the DHCA group, which might have influenced outcome.

Dr Edward D. Verrier (Seattle, Wash). How did you account for such a low bypass time because cooling and warming would necessarily take longer with DHCA? Was it just the ease of repair?

Dr Tassani. As a matter of fact, DHCA makes the surgical repair in most cases easier. Under such conditions, cooling and rewarming took about 20 minutes each, and total bypass time averaged around 40 minutes. The circulatory arrest time was not added to the bypass time. So we had, in this group, 2 bypass periods, one for cooling and one for rewarming. Surgical repair was performed under DHCA conditions. Total CPB time in the LF group was significantly longer, about 80 minutes, which might have influenced the different outcomes in both groups. 